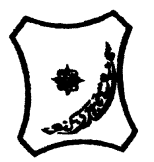

Bayero Journal of Pure and Applied Sciences, 11(2): 149 - 155

Received: November, 2018

Accepted: December, 2018

ISSN $2006-6996$

\title{
ANALYSIS OF CARBON STOCK DENSITY IN PROTECTED AND NON- PROTECTED AREAS OF GUINEA SAVANNA IN NIGER STATE, NIGERIA
}

\author{
Jibrin, A., ${ }^{1 *}$ Jaiyeoba, I.A. ${ }^{2}$ and Oladipo, E.O. ${ }^{3}$ \\ ${ }^{1}$ Department of Geography, Ahmadu Bello University, Zaria, Nigeria \\ ${ }^{2}$ Department of Geography, Federal University, Lokoja, Nigeria \\ ${ }^{3}$ Department of Geography, University of Lagos, Lagos, Nigeria \\ *Correspondence: abdullahi717@hotmail.com; +234-803-697-8420
}

\begin{abstract}
Quantification of carbon stock has gained major attention in international climate change mitigation and adaptation negotiations. However, poor knowledge of the quantity of carbon stock in respective ecosystems is one major challenge in estimating carbon stock in developing countries. This study is aimed at estimating and comparing carbon stock density of protected (forest reserve) and non-protected (parkland) areas of guinea savanna in Niger state. The research methodology includes field survey inventory, biometric measurements and laboratory analysis. At each of the 45 sampling plot locations, Carbon stock was measured from six pools viz above ground tree, undergrowth, dead wood, litter, root and soil, within a quadrat sampling plot of 500 m $^{2}$. Four fixed size square frames encompassing $1 \mathrm{~m}^{2}$ was used for the undergrowth (shrubs and grasses) and litter. Composite soil samples (for organic carbon) and undisturbed samples (for bulk density) were taken from each of the $1 \mathrm{~m}^{2}$ subplot quadrants at two depths $(0-15 \mathrm{~cm}$ and $15-30 \mathrm{~cm})$. Soil organic carbon concentration was estimated in the laboratory using Walkley-Black method. The findings of the study revealed that in terms of carbon stock in respective pools, in both protected and non-protected areas, soil pool was the highest, followed by tree and undergrowth; while litter, dead wood and root were the least in carbon stock. The average aggregate carbon stock density in the protected area is $118.2 \mathrm{Mg} \mathrm{ha}^{-1}$ which is greater than $69.3 \mathrm{Mg} \mathrm{ha}^{-1}$ recorded in the nonprotected area. It was also observed that there is significant difference in carbon stock density between the forest reserve and parkland study sites where $t(43)=18.34, p<0.001)$. The study concludes that if savannas were to be protected from fire, grazing and anthropogenic disturbances, most of them would accumulate substantial carbon and the sink would be larger; with a view to mitigating climate change effect.
\end{abstract}

Keywords: Carbon stock, climate change, density, guinea savanna, mitigation

\section{INTRODUCTION}

Carbon stock implies the quantity of carbon in a given pool or pools per unit area (Pearson, et al., 2005). Quantification and monitoring of carbon stock has gained major attention in international climate change mitigation and adaptation negotiations because verification and accounting of carbon stock in forest ecosystems have been recognized as potential strategies to reduce and stabilize atmospheric greenhouse gas concentrations (United Nations Framework Convention on Climate Change-UNFCCC, 2010).

The international concern with carbon emissions and sequestration assessments require adequate coverage of locally quantified carbon stocks (Inter Governmental Panel on Climate Change- IPCC, 2006). However, several authors (Brown and Lugo, 1992; Chidumayo, 2002; Salis et al., 2006; Williams et al., 2008; Lewis et al., 2009) have commented on the relative dearth of quantitative estimates for dry forests and savannah biome relative to moist tropical forests biome. According to Brown and Lugo (1992), forest inventories are valuable sources of data for estimating biomass density, but inventories for the tropics are few in number and their quality is poor.
Lewis et al. (2009) noted that very few information on carbon stock are available for the tropical forests and the savannah woodlands. Similarly, Williams et al. (2008) posited that inventories in the tropics are generally inadequate, particularly in view of the high rates of land-use change, fire disturbance, and land degradation which could result in heterogeneous carbon density in such ecosystems.

The savanna biome is characterized by co-dominance of trees and grasses, but ranges from grasslands where trees are virtually absent to more forest-like woodland ecosystems (Guinea Savanna) where trees are dominant (Pullan, 1974). A protected area is defined by International Union for Conservation of Nature - IUCN (2008) as a "clearly defined geographical space, recognized, dedicated and managed, through legal or other effective means, to achieve the long term conservation of nature with associated ecosystem services and cultural values". The unprotected areas are parklands that are assumed to have similar environmental conditions but are rather not protected by status. Parklands are defined as landscapes in which mature trees occur scattered in cultivated or recently fallowed fields (Pullan, 1974). 
BAJOPAS Volume 11 Number 2 December, 2018

Fire, logging, shifting cultivation and grazing in the savannas substantially reduce the stock of carbon. Conversely, protection from fire, deforestation and grazing causes these savannas to become closed canopy woodlands with accumulated high carbon stock.

The aim of the study is to quantify and compare carbon stock density of plant communities in the protected Kpashimi Forest Reserve and non-protected adjoining parkland area of guinea savanna in Niger state. Due to the shortfall of carbon stock research for ecological landscapes in Nigeria, it is logical that this gap in knowledge be bridged particularly for the savanna ecological areas characterized by heterogeneous plant communities.

\section{CONCEPTUAL FRAMEWORK}

The key ecosystem variable that determines carbon stock in a forest is the Net Primary Production -NPP (Malhi et al., 2011). NPP is defined as the rate of concurrent accumulation of organic matter by vegetation and equals the difference between total carbon assimilated by plants through photosynthesis (GPP -Gross Primary Productivity) and the carbon consumed by plant autotrophic respiration $R_{a}$ (Chapin et al., 2002). NPP represents the net new carbon stored as biomass in stems, leaves or roots of plants and defines a balance between GPP and autotrophic respiration $R_{a}$ (Malhi et al., 2011). The classic model for the net primary production of ecosystem is given by equation 1

$\mathrm{C} / \mathrm{m}^{2} / \mathrm{yr}$ ).................(eq. 1 )

$$
G P P\left(\mathrm{~g} \mathrm{C} / \mathrm{m}^{2} / \mathrm{yr}\right)=N P P\left(\mathrm{~g} \mathrm{C} / \mathrm{m}^{2} / \mathrm{yr}\right)+R_{a}(\mathrm{~g}
$$

Thus, the quantity of carbon stock can be estimated as equation 2

$$
\begin{aligned}
& N P P\left(\mathrm{~g} \mathrm{C} / \mathrm{m}^{2} / \mathrm{yr}\right)=G P P\left(\mathrm{~g} \mathrm{C} / \mathrm{m}^{2} / \mathrm{yr}\right)-R_{a}(\mathrm{~g} \\
& \mathrm{C} / \mathrm{m}^{2} / \mathrm{yr} \text { ).................(eq. 2) }
\end{aligned}
$$

\section{MATERIALS AND METHODS}

\section{Study Site}

The study area is located between latitude $8^{\circ} 40^{\prime}$ to $8^{\circ}$ 52' North and $6^{\circ} 39^{\prime}$ to $6^{\circ} 4^{\prime} 9^{\prime}$ East covering approximately 213.101 kilometres square (Figure 1). It is characterized by alternating wet and dry season climate coded as ' $A w^{\prime}$ ' by Koppen's classification. The mean annual rainfall is about $1,400 \mathrm{~mm}$ with mean annual temperature of about $28^{\circ} \mathrm{C}$ (Ojo, 1977). The geology of the study area is made up of cretaceous sedimentary rocks underlain by the Precambrian basement complex rocks (Forest Management Evaluation and Co-ordinating Unit -FORMECU, 1994). Phytogeographically, the study area lies within the southern Guinea savannah zone classified as woodland savannah vegetation with the understory dominated by annual grasses (Keay, 1953).

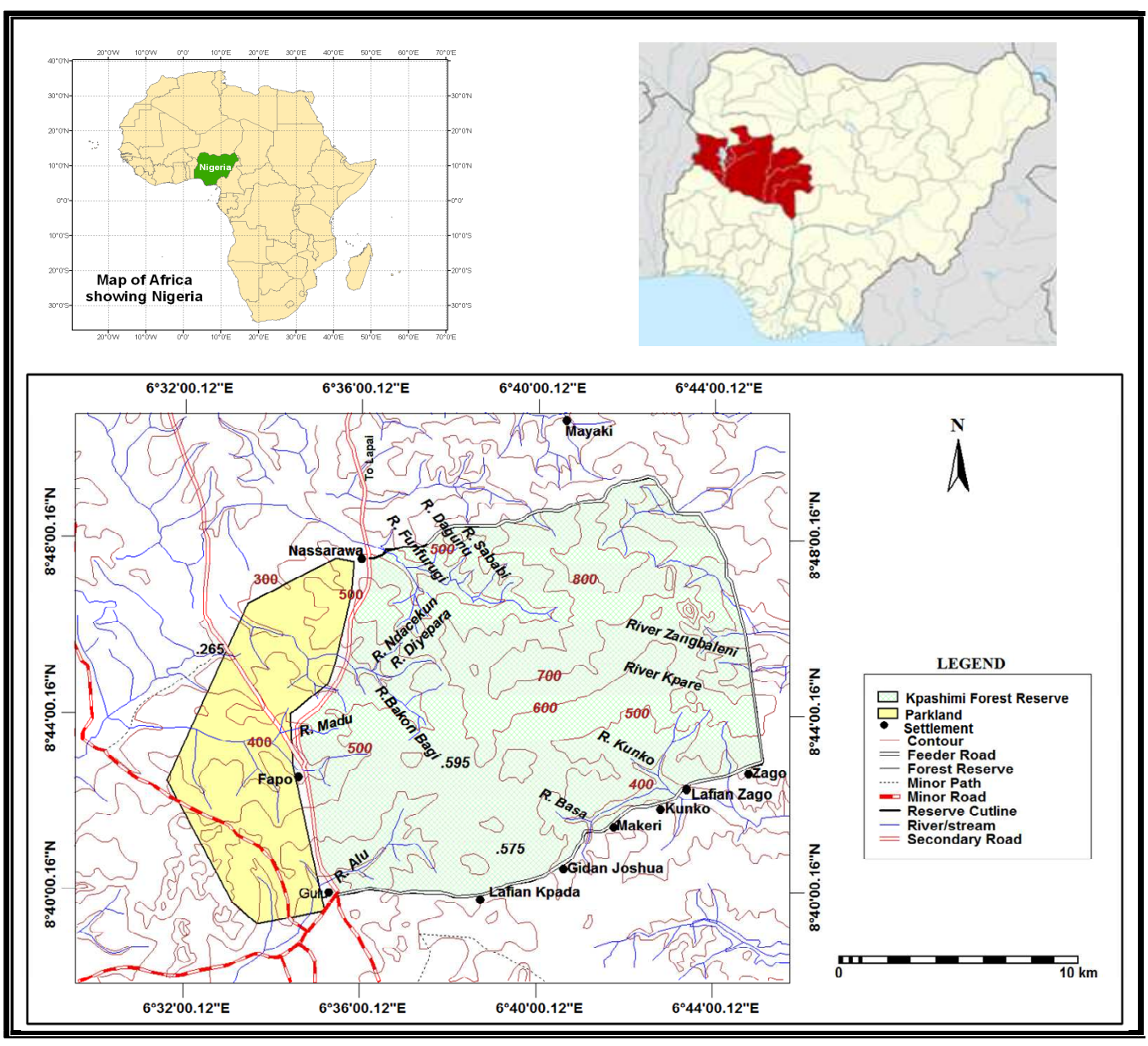

Figure 1: Geographical location of study area 


\section{MATERIALS AND METHODS}

The research methodology featured field survey sampling, morphometric measurements and laboratory analysis. Reconnaissance survey was conducted at the preparatory stage and was followed by a pilot survey; for the determination of sampling frame. The detailed fieldwork for the project took place from September to October, 2015. A total of 45 sampling units (n) was determined for the study based on calculations using the formula. Figure 2 shows the sample plots layout covering the entire study area.

$$
n=\frac{C V^{2} t^{2}}{E^{2}} \quad(\text { Philip, 1994) }
$$

Where:

$\mathrm{CV}=$ is the coefficient of variation of tree basal area at breast height

$t=$ is the $t$ value for the $95 \%$ confidence interval.

$\mathrm{E}=$ is the allowable sample error of estimation.

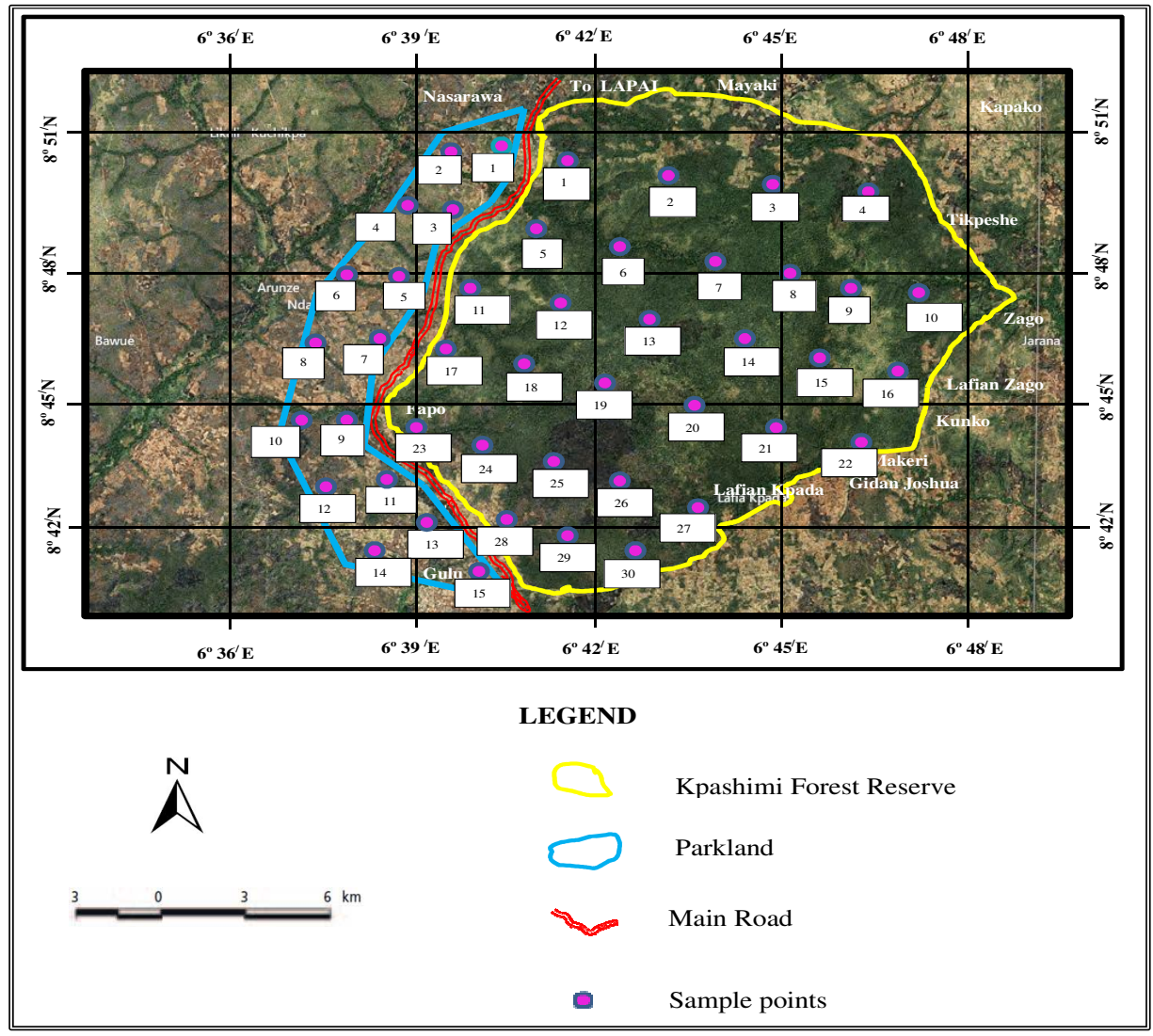

Figure 2: Location of Sample plot over the study area

At each of the 45 sampling plot locations, Carbon stock was measured from six pools namely above ground tree, undergrowth, dead wood, litter, root and soil. within a quadrat sampling plot of $500 \mathrm{~m}^{2}$. Four fixed size square frames encompassing $1 \mathrm{~m}^{2}$ was used for the undergrowth (shrubs and grasses) and litter. Composite soil samples (for organic carbon) and undisturbed samples (for bulk density) were taken from each of the $1 \mathrm{~m}^{2}$ subplot quadrants at two depths $(0-15 \mathrm{~cm}$ and $15-30 \mathrm{~cm})$. Soil organic carbon concentration was estimated in the laboratory using Walkley-Black method. Measurement of carbon in the respective pools was carried out based on the techniques presented in table 1.

TABLE 1: Carbon Pool measurement techniques

\begin{tabular}{llll}
\hline \hline S. No & Pool & Method & Source \\
\hline 1. & Above ground tree & Phytomass sampling / allometry model & Walker et al (2012) \\
2. & Below ground tree Root & Allometry model & Pearson et $a$ l (2005) \\
3. & Undergrowth & Clip plot method & MacDicken, (1997) \\
4. & Dead wood & Line transect method & Walker et al (2012) \\
5. & Litter & Clip plot method & Pearson et al (2005) \\
6. & Soil & Soil core / Laboratory analysis & MacDicken (1997)
\end{tabular}


BAJOPAS Volume 11 Number 2 December, 2018

All laboratory analysis were carried out at the Soil Science Laboratory, School of Agriculture and Agricultural Technology, Federal University of Technology, Minna, Niger State. Both descriptive and inferential statistics were used for data analysis. The descriptive statistics used to summarize the data include average mean, standard deviation, standard error, percentage, minimum and maximum values. The student's $t$-test was used to test for differences in carbon stock at 0.001 significant level.

\section{RESULTS AND DISCUSSION}

The carbon stock density in the respective pools is presented in Table 2. It shows that within the forest reserve, carbon stock in the above ground tree pool range from 7.3 to $26.8 \mathrm{Mg} \mathrm{ha}^{-1}$ while the parkland stored less (between 2.0 to $6.1 \mathrm{Mg} \mathrm{ha}^{-1}$ ). Carbon stock in the tree pool is also more variable in the forest reserve than in the parkland as indicated by values of standard deviation. The undergrowth pool carbon stock in the forest reserve varied from 6.8 to $19.9 \mathrm{Mg}$ $\mathrm{ha}^{-1}$, whereas in the parkland variability was lower with carbon stock ranging from 11.6 to $21.1 \mathrm{Mg} \mathrm{ha}^{-1}$. This indicates that the parkland has more carbon stock in the undergrowth pool than the forest reserve.

TABLE 2: Summary of carbon stock density in pools $\left(\mathrm{Mg} \mathrm{ha}^{-1}\right)$

\begin{tabular}{|c|c|c|c|c|c|c|}
\hline POOL & SITE & $\mathbf{N}$ & Minimum & Maximum & Mean & $\begin{array}{l}\text { Standard } \\
\text { Deviation }\end{array}$ \\
\hline \multirow{2}{*}{ Tree } & Forest Reserve & 30 & 7.27 & 26.78 & 16.55 & 4.64 \\
\hline & Parkland & 15 & 2.01 & 6.13 & 3.68 & 1.37 \\
\hline \multirow{2}{*}{ Undergrowth } & Forest Reserve & 30 & 6.80 & 19.90 & 12.09 & 3.19 \\
\hline & Parkland & 15 & 11.60 & 21.10 & 15.43 & 2.76 \\
\hline \multirow{2}{*}{ Dead Wood } & Forest Reserve & 30 & 1.81 & 6.71 & 3.92 & 1.45 \\
\hline & Parkland & 15 & 0.00 & 1.66 & 0.56 & 0.54 \\
\hline \multirow{2}{*}{ Litter } & Forest Reserve & 30 & 1.90 & 6.20 & 4.02 & 1.07 \\
\hline & Parkland & 15 & 1.20 & 2.60 & 1.76 & 0.46 \\
\hline \multirow{2}{*}{ Root } & Forest Reserve & 30 & 1.32 & 4.47 & 2.86 & 0.76 \\
\hline & Parkland & 15 & 0.38 & 1.06 & 0.67 & 0.23 \\
\hline \multirow{2}{*}{ Soil } & Forest Reserve & 30 & 64.20 & 91.60 & 78.76 & 6.87 \\
\hline & Parkland & 15 & 35.30 & 53.90 & 47.22 & 4.86 \\
\hline Aggregate Carbon & Forest Reserve & 30 & 93.99 & 139.98 & 118.19 & 9.40 \\
\hline Stock $\left(\mathrm{Mg} \mathrm{ha}^{-1}\right)$ & Parkland & 15 & 56.51 & 79.81 & 69.33 & 5.92 \\
\hline
\end{tabular}

Source: Fieldwork, 2015

Comparatively, the forest reserve carbon stock in the dead wood, litter and root pools range from 1.8-6.7 $\mathrm{Mg} \mathrm{ha}{ }^{-1}$, 1.9-6.2 Mg ha-1, 1.3-4.5 Mg ha-1 respectively; while in the parkland, carbon stock in the same pools (dead wood, litter and root) range from 0-1.7 Mg ha-1, $1.2-2.6 \mathrm{Mg} \mathrm{ha}^{-1}, 0.4-1.1 \mathrm{Mg} \mathrm{ha}^{-1}$ respectively. This shows that carbon stock in dead wood, litter and root pools were greater and more variable in the forest reserve than in the parkland based on the standard deviation values. Soil carbon pool contains between 64.2 to $91.6 \mathrm{Mg} \mathrm{ha}^{-1}$ of carbon stock in the forest reserve; whereas the parkland contains about 35.3 to $53.9 \mathrm{Mg} \mathrm{ha}{ }^{-1}$. Therefore, carbon stock in the soil pool within the forest reserve

\section{Forest Reserve}

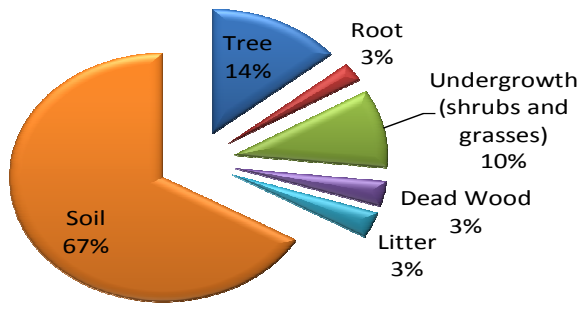

almost doubles that contained in the parkland soil pool.

Data analysis of the mean carbon stock in the respective pools shows that the amount of carbon stock in respective pools in decreasing order of quantity within the forest reserve are soil $>$ tree $>$ undergrowth $>$ litter $>$ dead wood $>$ root. Comparatively, the decreasing order of quantity in the parkland are soil > undergrowth $>$ tree $>$ litter $>$ root $>$ dead wood $>$. It can be observed that in both study sites (Forest reserve and parkland), soil carbon stock was the highest in magnitude, while dead wood and root were the least in carbon stock. The percentage distribution of the mean carbon stock in the respective pools is illustrated in figure 3 .

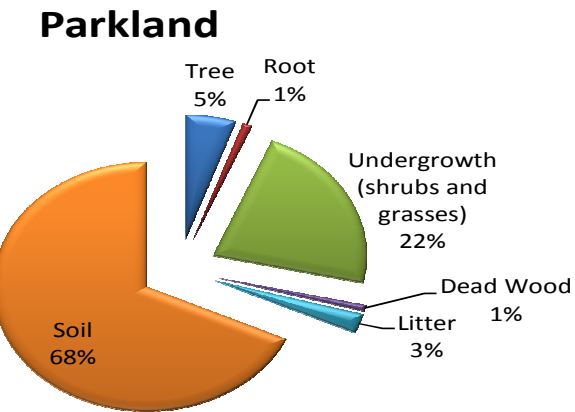

Figure 3: Distribution of the mean carbon stock in the respective pools Source: Fieldwork, 2015 
Over all, it can be observed that the average aggregate carbon stock density in the forest reserve is $118.2 \mathrm{Mg} \mathrm{ha}^{-1}$ which is greater than $69.3 \mathrm{Mg} \mathrm{ha}^{-1}$ recorded in the parkland. When the analysis of differences in carbon stock density between the forest reserve and the parkland was carried out, the student $t$-test revealed that there is significant difference in carbon stock density between the forest reserve and parkland study sites where $t(43)=18.34, p<$ 0.001 ). The higher organic carbon content of the forest reserve reflects a high organic matter turn over and fewer disturbances through tillage and harvesting operations. Comparative analysis of carbon stock density revealed that the mean carbon stock density obtained for the study area in this study was $103 \mathrm{Mg}$ $\mathrm{ha}^{-1}$ with a rage of $60-140 \mathrm{Mg} \mathrm{ha}^{-1}$ while the forest reserve study site has mean carbon stock density of $118.2 \mathrm{Mg} \mathrm{ha}^{-1}$ (range 94-140 $\mathrm{Mg} \mathrm{ha}^{-1}$ ) which is comparatively lower than closed-canopy evergreen forests in Africa, with an average estimate of $200 \mathrm{Mg}$ $\mathrm{ha}^{-1}$; ranging $174-244 \mathrm{Mg} \mathrm{ha}^{-1}$ (Lewis et al., 2009); and a range of $150-250 \mathrm{Mg} \mathrm{ha}^{-1}$ reported by FPAN (2010) for seasonally dry forests. Also, Munishi and Shear (2004) reported over $300 \mathrm{Mg} \mathrm{ha}^{-1}$ carbon stock in Tazanian Eastern Arc afromontane forests. The mean carbon stock density of the study area is also lower than the biome average estimate $137 \mathrm{Mg} \mathrm{ha}^{-1}$ for Tropical savannahs by Trumper et al. (2009) and Epple (2012).

Findings presented on carbon stock density (in pools and site) shows that, differences in carbon storage between study sites reflect variation in a number of factors; including plant community structure, composition, diversity, disturbance history, and successional stage. This is in conformity with previous studies such as Brown and Lugo (1992), Grace et al. (2006), Williams et al. (2008), FPAN (2010). The observed differences in carbon stock between the forest reserve and parkland can be explained by the contrasting peculiar physiognomic and composition attributes of the two study sites.

There is increasing concern that loss of mature trees in landscapes subjected to deforestation and degradation, as well as intense fires may result in the transformation of woodlands into scrublands, grasslands or parklands (Ribeiro et al., 2008; Druce, Pretorius and Slotow, 2008; Owen-Smith et al., 2006) with the associated loss of biodiversity and biomass and thus a decrease in carbon stocks. Consequently, parkland study sites tend to have reduced carbon contents due to reduced tree cover and increased mineralization as a result of surface disturbance. Since abundance of herbs and shrubs undergrowth favour higher organic carbon stock (Jaiyeoba, 1995; 1998; Lal, 2002; Anikwe et al., 2003), the higher organic carbon content of the forest reserve reflects a high organic matter turn over due to conservation and fewer disturbances through tillage and harvesting operations (Jaiyeoba, 1995). It is noteworthy that bush burning, logging, harvesting of Non Timber Forest Products, shifting cultivation and grazing in the savannas substantially reduce carbon stock (Jibrin,
2013; Jibrin, 2017), and determine the species composition to a large extent (Jibrin and Jaiyeoba, 2013). However, where there is effective protection from fire, deforestation and grazing these areas could become savanna woodland forests having high biomass density; with substantial carbon stock (Grace et al 2006; Jibrin et al., 2014). The carbon stock in forest ecosystems thus depend on forest type, forest density and productive capacity of the site and thus varies even within a specific forest ecosystem (Malhi et al., 1999). The stock may increase due to growth of young trees, as well as regeneration of new ones leading to increase in the density of forest stands (Malhi and Grace, 2000). On the other hand, it may decrease due to forest fires, disease, wind storms, drought, failure in protection/illegal logging or advance of the agricultural frontier into the site (Jibrin, 2016). In view of the foregoing analysis, the carbon stock density would vary between protected areas and non-protected areas in any ecological landscape. The degree of such variation will only be determined by whether there is significant differences or not; as shown in this study.

\section{CONCLUSION AND RECOMMENDATION}

In conclusion, this study reveals that there is statistically significant difference in the spatial distribution of carbon stock over the study area; particularly between the protected and non-protected areas. Considering the degradation status of the vegetation in the non-protected areas, apparently, there is tremendous capacity for the study area to store carbon and act as carbon sink if properly managed by protection. This study thus provides more accurate and reliable estimate of carbon stock in the study area; which eliminates the problem of uncertainties associated with biome average estimates. It also provides a benchmark against which future estimates of carbon stock can be compared, and sets a baseline for calculating changes in carbon stocks over time. This study suggests that forestry based carbon offset projects can be effective in mitigating global carbon emissions from deforestation and forest degradation in the study area. In view of the observed potentials of carbon sequestration capacity in the study area, this study recommends the need for defining a concrete community based sustainable forest management such as carbon offset trading by local communities which will provide window of opportunities for accessing carbon credits through the Clean Development Mechanism (CDM) tool of the Kyoto Protocol under the United Nations Framework Convention on Climate Change (UNFCCC).

\section{Acknowledgement}

We are thankful to the staff of the Niger State Forestry Division, Ministry of Environment, Minna; for granting us official permission and technical support for this research. We are also indebted to the staff of the Kpashimi Forest Reserve, Lapai, Niger state who helped in field data collection for this study. 
BAJOPAS Volume 11 Number 2 December, 2018 Authors' Contribution

The entire research work was planned and executed by Jibrin, A., under the supervision of Prof. Jaiyeoba, I.A. and Prof. Oladipo, E.O; who both contributed

\section{REFERENCES}

Anikwe, M.A.N., Obi, M.E., Agbim, N.N. (2003). Effect of crop and soil management practices soil compactibility in maize and groundnut plots in a Paleustult in southeastern Nigeria. In: Plant and Soils, 253:457-465.

Brown, S. and Lugo, A.E. (1992). 'Above ground biomass estimates for tropical moist forests of the Brazilian Amazo'. In: Interciencia 17:8-18.

Chapin, F. S. III., Matson, P. A., and Mooney, H. A. (2002). Principles of Terrestrial Ecosystem Ecology, New York, USA, Springer-Verlag.

Chidumayo, E. N. (2002). Charcoal potential in southern Africa - Final Report for Zambia, INCODEV, Stockholm, Stockholm Environment Institute.

Druce, H.C., Pretorius, K., Slotow, R (2008). The response of an elephant population to conservation area expansion: phinda private game reserve. In: South Africa. Biol Conservation, 141(12):3127 3138.

Epple, C. (2012). The climate relevance of ecosystems beyond forests and peatlands: $A$ review of current knowledge and recommendations for action. - BfN-Skripten 312. Bonn (German Federal Agency for Nature Conservation), 52 p. Available from http://www.unepwcmc.org/medialibrary/2012/08/02/9607aa2 1/Epple2012Ecosystems.pdf.

FORMECU (1994). Forest Management Evaluation and Co-ordinating Unit (1994) World Bank/Government of Nigeria Forestry III project Vol. VI Environmental Assessment, Forest Management Component, kpashimi Forest Reserve, Final Draft.

FPAN-Forest Philanthropy Action Network (2010). African Tropical Forests Review of the scientific literature and existing carbon projects: July 2010, Wales, UK.

Grace, J., San Jose. J., Meir, P., Miranda, H.S., and Montes, R. A. (2006). 'Productivity and carbon fluxes of tropical savannas'.In Journal of Biogeography, Vol. 33 (3) pp 387-400. Available http://doi.wiley.com/10.1111/j.13652699.2005.01448.x [Accessed June 21, 2011].

IPCC Inter-governmental Panel On Climate Change. (2006). IPCC Guidelines for National Greenhouse Gas Inventories. Prepared by the National Greenhouse Gas Inventories Programme. Edited by H.S. Eggleston, L Buendia, K Miwa, T Ngara and K Tanabe. Japan, Institute For Global Environmental Strategies. immensely in the design of methodology and provided inputs in the analysis of data. ,

\section{Conflict of Interest}

There is no conflict of interest among the authors.

IUCN (2008); Guidelines for Applying the IUCN Protected Area Management Categories, IUCN, Dudley, N. [editor] Gland, Switzerland

Jaiyeoba, I.A. (1995). Changes in soil properties relation to different land uses in part of Nigerian semi-arid savanna. In: Soil Use and Management (11). 84-89

Jaiyeoba, I.A. (1998). Building-up of organic matter and nutrients under fallow in a tropical rain forest environment, Nigeria. In: Malaysian Journal of Tropical Geography, (18). 10-16.

Jibrin, A. (2013). A Study of Variation in Physiognomic Characteristics of Guinea Savanna Vegetation, In: Environment and Natural Resources Research, Toronto 3(2), 52-60. doi:10.5539/enrr.v3n2p52

Jibrin, A., \& Jaiyeoba, I. A. (2013). Characterization of Structural Composition and Diversity of Vegetation in the Kpashimi Forest Reserve, Niger State, Nigeria, In: Journal of Geography and Geology , Toronto 5(3), 7587. doi:10.5539/jgg.v5n3p75

Jibrin, A., Mohammed S. Z., Abdulkadir, A. Kaura, S.J, Amos, B.B. (2014). Carbon sequestration potential of Kpashimi forest reserve, Niger state, Nigeria. In: International Journal of Geography and Geology, Punjab.3(12):Pp145-158 DOI: 10.18488/journal.10/2014.3.12/10.12.145.15 8 (Online ISSN:2305-7041 Print ISSN: 2306-9872) Publisher: Pakinsight Publishing Group.

Jibrin A. (2016) Biomass and Carbon Stock Density of Kpashimi Forest Reserve and Adjoining Parkland Area, Niger State, Nigeria. An unpublished Ph.D. Research Dissertation, Department of Geography, Ahmadu Bello University, Zaria, Nigeria

Jibrin, A. (2017) 'Ecological Landscape Analysis of Savanna Woodland Area in Niger State, Nigeria' In: Zaria Geographer, Zaria. Volume 24 (1) Pp 119-131. (ISSN 0795-7599). Publisher: Department of Geography, Ahmadu Bello University.

Keay, R.W.J. (1953). An outline of Nigerian Vegetation, 2nd Edition, Lagos. Government Publisher.

Lal, R. (2002). Soil carbon dynamic in cropland and rangeland. In: Environmental Pollution, 116:353-362.

Lewis, S.L., Lopez-Gonzalez, G., Sonke', B., AffumBaffoe, K., Baker, T.R., Ojo, L., Phillips, O.L., Reitsma, J., White, L., Comiskey, J., Ewango, C., Feldpausch, T., Hamilton, A.C., Gloor, M., Hart, T., Hladik, A., Kamdem, M.N., Lloyd, D. Lovett, J., Makana, J., Malhi, J.R., Mbago, Y., Ndangalasi, F.M., Peacock, H.J., Peh, K.S., , Sheil, D., Sunderland, T., Swaine, M.D., 
BAJOPAS Volume 11 Number 2 December, 2018 Taplin, J., Taylor, D., Thomas, S., Votere, R. and Wo"ll, H. (2009). Increasing carbon

MacDicken, K.G. (1997). A Guide to Monitoring Carbon Storage in Forestry and Agroforestry Projects. Winrock International Institute for Agriculture Development, Arlington, California.

Malhi, Y., Baldocchi, D.D., Jarvis, P.G., (1999). The carbon balance of tropical, temperate and boreal forests. In: Plant, Cell and Environment 22, 715-740.

Malhi, Y. and Grace, J., (2000).'Tropical forests and atmospheric carbon dioxide'. In: Trends in Ecology and Evolution 15, 332-337.

Malhi, Y., Doughty, C., Galbraith, D. (2011). The allocation of ecosystem net primary productivity in tropical forests. In: Philosophical Transactions of the Royal Society - B 366:3225-3245.

Munishi, P.K.T. and Shear, T.H. (2004). Carbon storage in afromontane rain forests of the eastern arc mountains of tanzania: their net contribution to atmospheric carbon. In: $J$. Trop. For. Sci. 16, 78-98.

Ojo, O. (1977). The climates of West Africa. London: Heinemann.

Owen-Smith, N., Kerley, G.I.H., Page, B., Slotow, R., van Aarde, R.J. (2006). A scientific perspective on the management of elephants in the Kruger national park and elsewhere. In: South African Journal of Science, 102:389-394.

Pearson, Timothy, Sarah Walker, and Sandra Brown (2005). Sourcebook for Land Use, Land-Use Change and Forestry Projects. Winrock International and World Bank BioCarbon Fund.

Philip, M.S. (1994). Measuring Trees and Forests. 2nd edition. Oxford: CABI Publishing. 310pp.

Pullan, R.A. (1974). Farmed parkland in West Africa. In: Savanna, 3(2): 119-151. storage in intact african tropical forests. In: Nature 457, 1003-1006.

Ribeiro, N.S., Shugart H.H., Washington-Allen R.A. (2008). The effects of fire and elephants on species composition and structure of the Niassa Reserve, northern Mozambique. In: For Ecol Manage, 255:1626-1636.

Salis, S.M., Assis, M.A., Mattos, P.P., Piao, A.C.S., (2006). 'Estimating aboveground biomass and wood volume of a savanna woodland in Brazil's Panatal wetlands based on allometric correlations'. In: Forest Ecology and Management 228, 61-68.

Trumper, K., Bertzky, M., Dickson, B., van der Heijden, G., Jenkins, M., Manning, P. J. (2009). The Natural Fix? The role of ecosystems in climate mitigation. A UNEP rapid response assessment. United Nations Environment Programme, UNEPWCMC, Cambridge, UK. Available http://www.grida.no/publications/rr/naturalfix/

UNFCCC United Nations Framework Convention on Climate Change. (2010). "National Communications Annex I." Retrieved January 20, 2010, from http://unfccc.int/national_reports/annex_i_n atcom_/items/1095.php.

Walker, S.M., Pearson, T.R.H., Casarim, F.M., Harris, N., Petrova, S., Grais, A., Swails, E., Netzer, M., Goslee, K.M. and Brown. S. (2012). Standard Operating Procedures for Terrestrial Carbon Measurement. Version 2012. Winrock International.

Williams, M., Ryan, C.M., Rees, R.M., Sambane, E., Fernando, J., Grace, J., (2008). 'Carbon sequestration and biodiversity of re-growing Miombo woodlands in Mozambique'.In: Forest Ecology and Management 254, 145155. 